\title{
Foraminiferal morphogroups in dysoxic shelf deposits from the Jurassic of Spitsbergen
}

\author{
Jenö Nagy, ${ }^{1}$ Matías Reolid ${ }^{2}$ \& Francisco J. Rodríguez-Tovar ${ }^{3}$ \\ 1 Department of Geosciences, University of Oslo, P.O. Box 1047, Blindern, NO-0316 Oslo, Norway \\ 2 Departamento de Geología, Campus Las Lagunillas, Universidad de Jaén, ES-23071 Jaén, Spain \\ 3 Departamento de Estratigrafía y Paleontología, Universidad de Granada, Avenida Fuentenueva, ES-18071 Granada, Spain
}

Keywords

Foraminifera; Jurassic; morphogroups; microhabitats; palaeoenvironments; Spitsbergen.

\section{Correspondence}

Jenö Nagy, Department of Geosciences, University of Oslo, P.O. Box 1047, Blindern, No-0316 Oslo, Norway. E-mail:

jeno.nagy@geo.uio.no

doi:10.1111/j.1751-8369.2009.00112.x

\begin{abstract}
Analysis of benthic foraminiferal assemblages was performed in Bathonian to Kimmeridgian deposits through a section covering the lower half of the Agardhfjellet Formation in central Spitsbergen. The section consists mainly of organic-rich shales, which contain low-diversity agglutinated assemblages. In this foraminiferal succession five morphogroups were differentiated according to shell architecture (general shape, mode of coiling and number of chambers), integrated with the supposed microhabitat (epifaunal, shallow infaunal and deep infaunal) and feeding strategy (suspension-feeder, herbivore, bacterivore, etc.). The environmental evolution of the analysed section is interpreted by using the stratigraphic distribution of morphogroups, combined with species diversities and sedimentary data, in a sequence stratigraphic framework. The section comprises two depositional sequences, which demonstrate that species diversity and relative frequency of morphogroups are correlative with transgressive-regressive trends controlling depth and oxygenation of the water column. In both sequences, the maximum flooding interval is characterized by increased organic carbon content, dominance of the epifaunal morphogroups and reduced species diversity: features reflecting the increased degree of stagnation separating the transgressive phase from the regressive phase.
\end{abstract}

As an approach to palaeoenvironmental assessment, benthic foraminiferal morphogroup analysis has attracted special attention over the last two decades. Following initial papers focused on the palaeoecological significance of foraminiferal morphology (Chamney 1976; Severin 1983), the morphogroup concept was introduced by Jones \& Charnock (1985). The concept was further developed in subsequent studies, and has been applied to interpret various aspects of the palaeoenvironment, such as food supply, oxygenation, substrate and salinity (Nagy 1992; Tyszka 1994; Bąk 2004; Szydlo 2004; Reolid et al. 2008; among others). The morphogroup approach in this paper is applied to a foraminiferal succession formed in mainly dysoxic environments, in order to recognize changing depositional conditions in a sequence stratigraphic framework.

\section{The analysed deposits}

Jurassic shelf environments characterized by changing oxygen levels are well represented in the Agardhfjellet Formation, which is extensively exposed in the Central Basin of Spitsbergen (Dypvik et al. 1991). This study deals with the lower $108 \mathrm{~m}$ of the Agardhfjellet Formation, comprising Bathonian, Callovian, Oxfordian and Kimmeridgian deposits, which have been logged and sampled from the Janusfjellet section, located in central Spitsbergen (Figs. 1, 2).

The lower part of the analysed interval corresponds to the Oppdalen Member, which begins with the Brentskardhaugen Bed, a transgressive conglomerate containing phosphatic pebbles. This is overlain by the Marhøgda Bed, consisting of ooids in a sandy matrix. The 
Fig. 1 Location map of Spitsbergen, Svalbard, showing the position of the studied section at Janusfjellet.

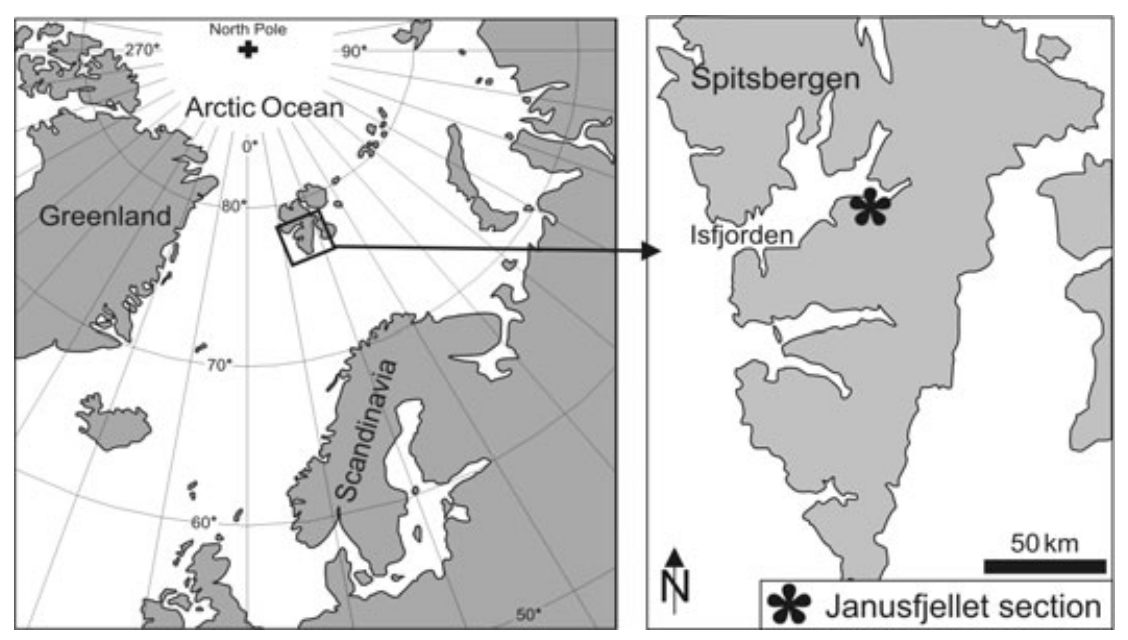

succeeding main body of the member reveals a finingupward development from fine sand and silt to shale. The Lardyfjellet Member consists mainly of finely laminated black shales with extremely high organic carbon content. These beds are overlain by the Oppdalssåta Member, which consists of dark silty shales interbedded with thin horizons of fine-grained, highly bioturbated sandstones. The upper part of the analysed section corresponds to the lower half of the Slottsmøya Member, consisting of laminated dark shales and grey silty shales.

\section{Materials and methods}

The succession studied preserves an essentially continuous benthic foraminiferal record, from which approximately 6700 specimens have been counted, in samples taken from 31 levels. Most of the samples were collected from well-indurated black shales that characterize the main body of the Agardhfjellet Formation. A smaller number of samples were taken from siltstones and fine-grained sandstones from the basal part of the formation. In the laboratory, the rock samples were disintegrated using the kerosene method described by Nagy et al. (1988). The most critical phase of the procedure is the sediment disintegration, which involves soaking the sediment in kerosene, followed by boiling the partly disintegrated sample in sodium hydroxide. A large number of shale samples required between one and three repetitions of this step of the procedure (combined with hydrogen peroxide) to obtain an adequate degree of disintegration.

\section{Morphogroups and subgroups}

A detailed analysis of the studied succession revealed a high abundance of agglutinated foraminifera, and the almost total absence of calcareous benthic specimens. In total, 35 agglutinated and two calcareous species have been observed. Calcareous forms occur in very few samples, where they compose $<1 \%$ of the assemblage. In the foraminiferal succession, five morphogroups are distinguished and are designated alphabetically from A to E (Fig. 3; Appendix). Two of these groups, C and D, are further subdivided into three and two subgroups, respectively. The differentiation of morphological categories is based on three types of criteria: (1) test morphology, comprising general outline, number of chambers, chamber arrangement and architecture; (2) life habitat, characterized as deep infaunal, shallow infaunal or epifaunal; and (3) supposed feeding strategies, characterized as suspension feeders, deposit feeders, herbivores or bacterial scavengers. A useful basis for the assignment of Jurassic genera to morphological categories and their environmental interpretation has accumulated as a result of several studies: Nagy (1992), Tyszka (1994), Nagy et al. (1995) and Reolid et al. (2008).

A morphogroup system developed for a given sedimentary succession is often cumbersome to apply directly to a new sedimentary succession, owing to major differences in the composition of assemblages, which are mainly determined by divergences in ecosedimentary conditions, and, commonly, differencences in stratigraphic age. This is also the case with the agglutinated foraminiferal succession of the Jurassic of Spitsbergen, which required the development of a modified morphogroup system suitable for the analysis of assemblages adapted to hypoxic marine shelf environments. The typical species of the Svalbard morphogroups are illustrated in Fig. 4. In addition, illustrations of common species occurring in the section analysed are illustrated in Nagy \& Basov (1998). 


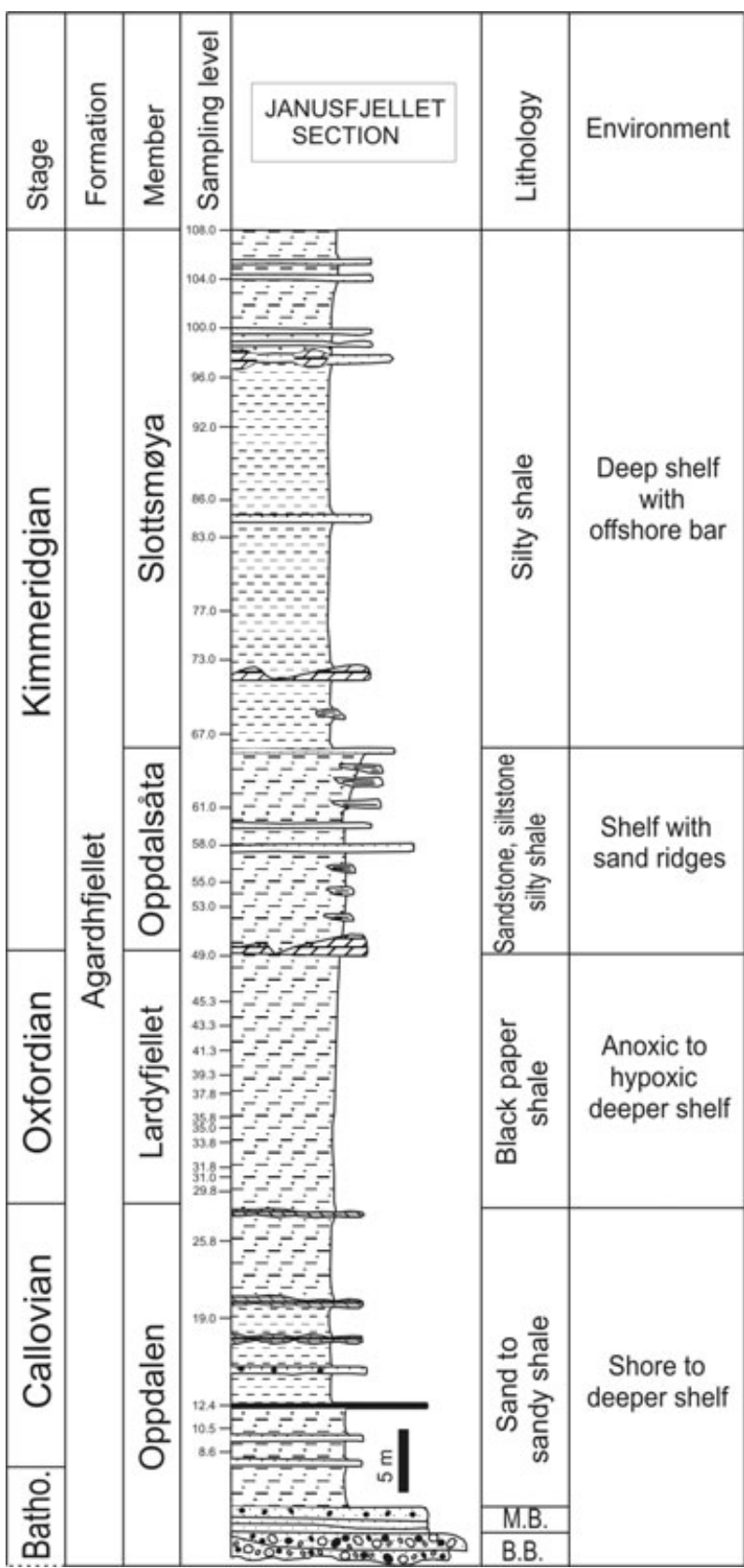

Fig. 2 Outline of the stratigraphy, lithology and environments of the Bathonian to Kimmeridgian part of the Agardhfjellet Formation in the Janusfjellet section, central Spitsbergen. (Lithological column redrawn and modified from Århus 1998.)

\section{Morphogroup A}

This morphogroup comprises species with tubular and unilocular shells. An epifaunal habitat and suspensivorous feeding strategies are supposed. The group is represented only by Rhizammina (Fig. 4a), and is equivalent to subgroup 1-a of Nagy (1992) and morphogroup A-1 of Tyszka (1994).

\section{Morphogroup B}

This category is represented by unilocular shells of spheric and subspheric shape. The organisms are interpreted as epifaunal, passive deposit feeders (Fig. 3), among which Thuramminoides is the representative genus (Fig. 4b). The morphogroup is equivalent to subgroup 2-a of Nagy (1992).

\section{Morphogroup C}

This morphogroup comprises species with elongated, subcylindric, multilocular shells, adapted to infaunal life habitats (Fig. 3). Three subgroups have been differentiated within the group.

Subgroup Cl consists of uniserial forms living as shallow to deep infaunal detritivorous bacterial scavengers. Reopax is the representative genus of this subgroup (Fig. 4c), which is equivalent to subgroup 3-b of Nagy (1992) and morphogroup A-8 of Tyszka (1994).

Subgroup C2 is composed of species having a planispiral or streptospiral initial stage, changing to a uniserial final stage. A shallow infaunal habitat and a detritivorous bacterial scavenger feeding strategy are inferred. Two genera, Ammobaculites (Fig. 4d) and Bulbobaculites, are registered in this subgroup. The subgroup corresponds to subgroup 3-b of Nagy (1992) and morphogroup A-6 of Tyszka (1994).

Subgroup C 3 consists of biserial, triserial and elongated trochospiral forms, adapted to shallow to deep infaunal habitats, with detritivorous bacterial scavenger feeding strategies. The genera included here are Eomarsonella, Dorothia, Verneuilina and Verneuilinoides (Fig. 4e). The subgroup correlates to subgroup 3-b of Nagy (1992) and morphogroup A-8 of Tyszka (1994).

\section{Morphogroup D}

This morphogroup includes species with spiral multilocular shells and epifaunal to shallow infaunal habitats, combined with herbivorous and detritivorous feeding strategies. Two subgroups are differentiated.

Subgroup Dl includes globular and plano-convex forms, with trochospiral coiling. Epifaunal herbivorous, detritivorous and active omnivorous feeding habits are interpreted. The registered genera are Ammoglobigerina and Trochammina (Fig. 4f). The subgroup is equivalent to subgroup 2-b of Nagy (1992) and morphogroup A-4 of Tyszka (1994).

Subgroup D2 is typified by rounded, planispiral morphotypes, adapted to epifaunal and potentially shallow infaunal habitats, with herbivorous, detritivorous and active bacterivorous behaviour. It is represented by the 


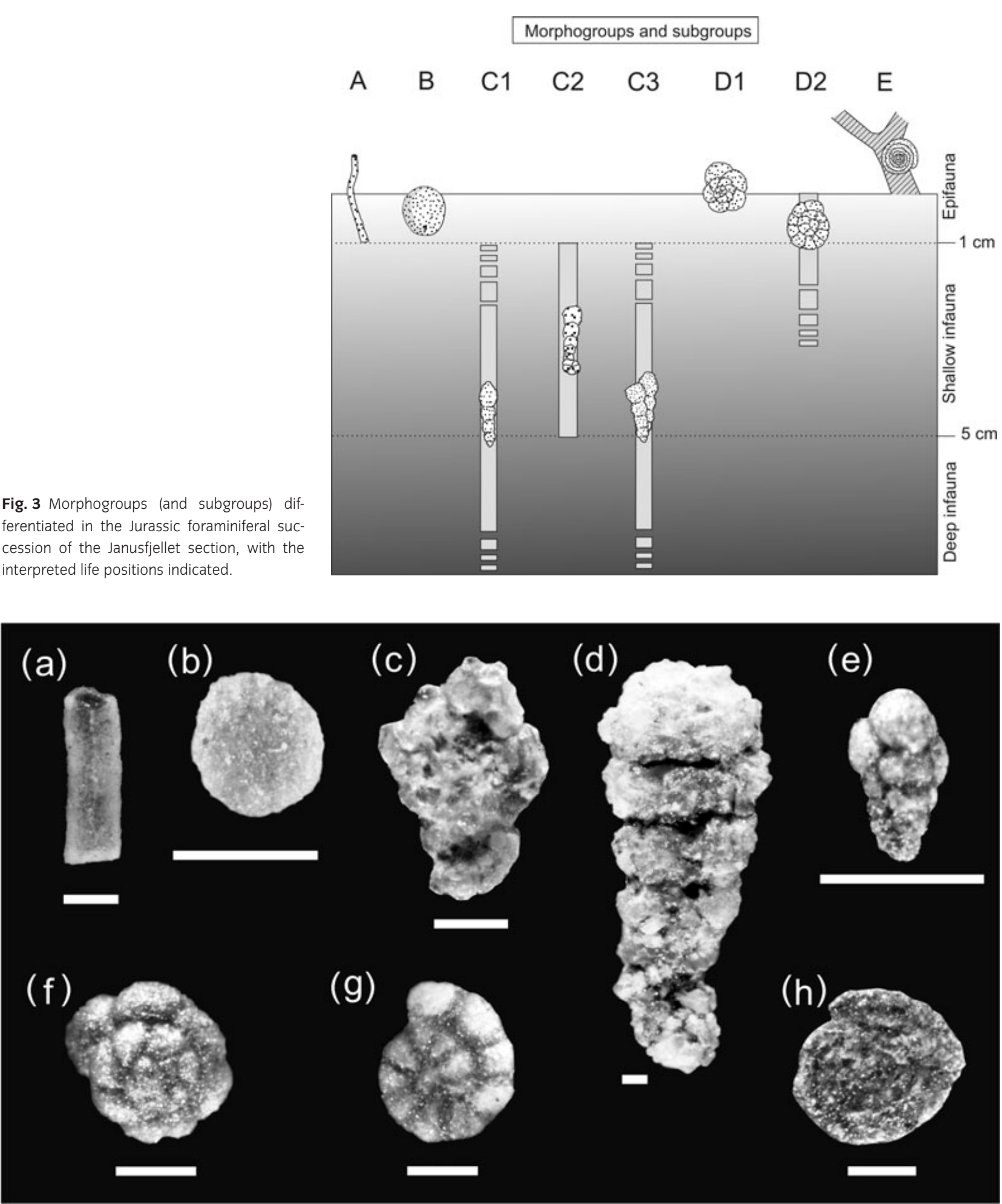

Fig. 4 Species exemplifying the foraminiferal morphogroups recognized in the Janusfjellet section: (a) Rhizammina sp., morphogroup A; (b) Thuramminoides sp., morphogroup B; (c) Reophax sterkii, subgroup C1; (d) Ammobaculites areniferus, subgroup C2; (e) Verneuilinoides aff. graciosus, subgroup C3; (f) Trochammina praerosacea, subgroup D1; (g) Recurvoides scherkalyensis, subgroup D2; (h) Ammodiscus sp., morphogroup E. Scale bars: 250 um. 
genera Haplophragmoides, Cribrostomoides and Recurvoides (Fig. 4g). This category correlates with subgroup 3-a of Nagy (1992) and morphogroup A-6 of Tyszka (1994).

\section{Morphogroup E}

This category includes flattened tests composed of two chambers (proloculus and second chamber), with planispiral or irregular coiling. An epifaunal to phytal lifestyle with herbivorous and detritivorous trophic strategies are interpreted. The genera Glomospira, Arenoturrispirillina and Ammodiscus (Fig. 4h) have been recognized. The morphogroup is equivalent to subgroup 4-a of Nagy (1992) and morphogroup A-3 of Tyszka (1994).

\section{Morphogroups of calcareous taxa}

The extremely rare calcareous faunal component comprising Lingulina and Lenticulina represent flattened multilocular morphotypes, with a potentially deep infaunal microhabitat, and depositivorous and grazing omnivorous trophic behaviours. Tyszka (1994) include these forms in morphogroups C-6 (Lingulina) and C-8 (Lenticulina).

\section{Morphogroup trends in a transgressive-regressive framework}

The base of the studied section is an erosional unconformity cutting the underlying Knorringfjellet Formation. This ravinement surface represents a sequence boundary, which became flooded by the regional Bathonian transgression. During the advancing transgression, a principally fining-upward succession was formed, reflecting the deepening upward depositional environment of the Oppdalen Member (Fig. 2). It starts with the Brentskardhaugen Bed, a beach conglomerate containing reworked phosphatic pebbles, followed by the sandy oolites of the Marhøgda Bed, which is succeeded by a fine sand to shale succession, forming the rest of the member.

No foraminifera were found in the lower, coarser part of the section (Fig. 5). Above this level, the number of species is relatively low, suggesting the effect of a restricting factor, possibly reduced salinity in surficial waters. The development of low salinity in the upper part of the water column can be explained by large freshwater discharge to the basin from the extensive adjacent land areas. The effect of this factor decreases upwards in the Oppdalen Member, as shown by the increasing species diversity. In the upper part of the member, there is a diversity reduction owing to decreasing oxygen levels, as evidenced by the increasing quantities of organic carbon.
The oxygen-depleted conditions in deeper water could be attributed to the density-stratified nature of the water column. The foraminiferal assemblages are dominated by the digging infaunal component (morphogroup C), followed by the epifaunal group (mainly B and D1). The deep-digging group is associated with low organic carbon content, which is mainly found in the middle part of the member.

The fining-upward succession of the Oppdalen Member terminates in the organic-rich black shale interval of the Lardyfjellet Member. These shales are finely laminated, papery in consistency and show high values of organic carbon (5.0-11.2\%). The foraminiferal assemblages reveal minimum values of diversity and a high dominance of the epifaunal morphogroups B and D1. The shallow infaunal component (groups C2 and D2) is strongly reduced, suggesting that the redox boundary was located close to the sediment-water interface, and that there was an absence of oxygen in the typical infaunal microhabitats. These features indicate dysaerobic to anaerobic bottom water conditions, which are most pronounced in this interval within the Agardhfjellet Formation. The high degree of stagnation is apparently related to the maximum flooding interval (Fig. 5).

The Oppdalssåta Member of dark silty shales and interbedded fine-grained sandstones shows a generally coarsening-upward trend, reflecting the shallowing of the depositional area during the regressive phase of the first subordinate sequence of the Agardhfjellet Formation. The Oppdalssåta Member sandstones were deposited as offshore bars (Dypvik et al. 1991), and their extremely high degree of bioturbation is in accordance with deposition under oxic conditions. The shales between the sandbars were deposited under dysaerobic conditions, however, as shown by their foraminiferal assemblages that are dominated by the shallow infaunal component, and reveal increased but still low species diversities (Fig. 5). The expansion of these two faunal parameters and the reduced organic carbon content indicate increased oxygenation, compared with the underlying maximum flooding interval.

There is a sharp lithological contact between the sandy Oppdalssåta Member and the dark shales of the overlying Slottsmøya Member. The contact represents a transgressive surface, introducing the second subordinate sequence, which constitutes the upper part of the Agardhfjellet Formation (Fig. 5). The transgressive phase of this sequence is characterized by moderate diversities and the high dominance of the shallow infaunal and potentially epifaunal morphogroups (C2 and D2). Higher up in the Slottsmøya Member, a maximum flooding interval is developed, as shown by the slightly increased stagnation, indicated by reduced species diversity, an expanded 


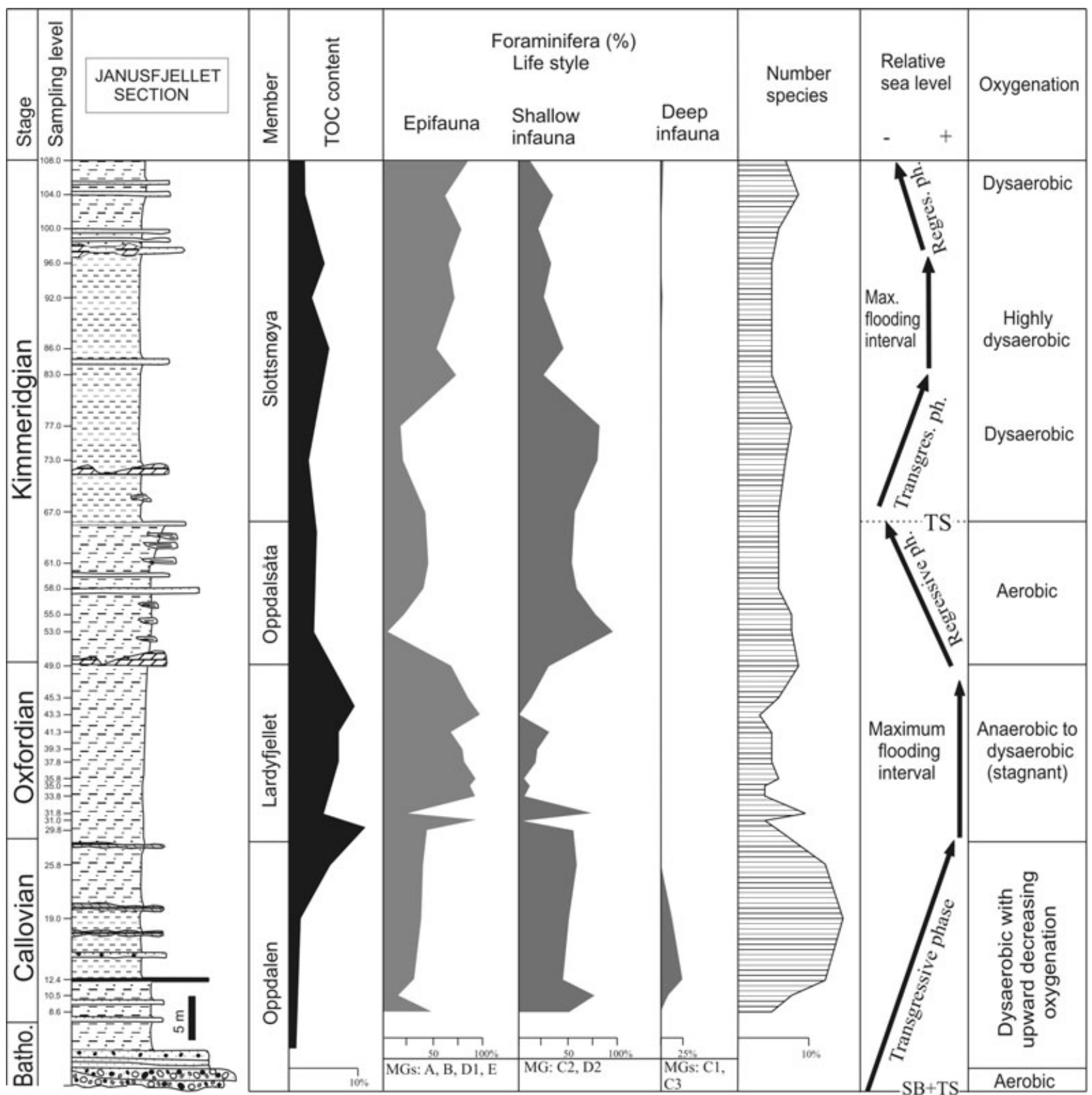

Fig. 5 The Janusfjellet section, with sedimentary features, morphogroup categories, diversities and oxygenation in a sequence stratigraphic framework. (Lithological column redrawn and modified from Århus 1998.)

epifaunal component (mainly morphogroup D1, and secondarily B) and increased organic carbon content. The rather weakly developed base of the regressive phase is signalled by increased diversity and reduced organic carbon content. This phase continues to the upper sequence boundary marking the top of the Agardhfjellet Formation.

\section{Conclusion}

Callovian to Kimmeridgian deposits, composing the lower half of the Agardhfjellet Formation in the Janusfjellet section, central Spitsbergen, consist mainly of shales with high to intermediate organic carbon content. Deposition of the shales took place mainly under 
dysaerobic conditions. This sedimentary succession contains an essentially continuous foraminiferal record, composed almost exclusively of agglutinated taxa forming low-diversity assemblages of restricted nature. The main restricting factor was reduced access to oxygen in benthic environments, owing to the salinity-induced stratification of the water column.

In the foraminiferal succession, five morphogroups (including five subgroups) have been differentiated, based on morphological features combined with inferred microhabitat preferences and feeding strategies. Morphogroup A comprises forms with tubular unilocular shells, and an inferred epifaunal suspension-feeding habit. Morphogroup B represents globular unilocular forms with an epifaunal, passive depositivorous mode of life. Morphogroup C contains three subgroups composed of elongated, subcylindrical and multilocular taxa, with an infaunal habitat and detritivorous bacterial scavenging: subgroup $\mathrm{Cl}$ of uniserial forms living in shallow to deep infaunal microhabitats; subgroup C2 with spiral initial stage and uniserial final part, living as shallow infauna; and subgroup C3 of biserial, triserial or elongated trochospiral forms, with shallow to deep infaunal strategies. Morphogroup D comprises spiral multilocular species living as detritivorous epifauna (potentially shallow infauna), divided into two subgroups: subgroup Dl, with globular and planoconvex shape, and trochospiral coiling, including herbivores, detritivores and active omnivores; and subgroup D2, including rounded planispiral species with herbivorous, detritivorous and active bacterivorous behaviour. Morphogroup E comprises flattened taxa, with a proloculus and a spiral or irregular second chamber, adapted to epifaunal to phytal, herbivorous and detritivorous modes of life.

The stratigraphic distribution of the morphogroups, combined with sedimentary data and species diversities, have been employed to delineate the palaeoenvironmental evolution of the Janusfjellet section, related to sealevel changes in a sequence stratigraphic framework. Sea-level changes controlled the oxygenation at the different microhabitat depths at, or below, the seabed surface, as reflected by the variation in morphogroup proportions and diversity.

In central Spitsbergen, the Agardhfjellet Formation (Bathonian to Ryazanian in age) comprises a major depositional sequence, which can be subdivided into two subordinate sequences. These two sequences are represented in the Bathonian to Kimmeridgian interval studied of the Janusfjellet section, although most of the regressive phase of the upper sequence is not included in this study. In both sequences the maximum flooding interval is characterized by the increased organic carbon content, the dominance of epifaunal foraminifera and the reduced species diversity: these features all indicate increased stagnation in benthic environments. The transgressive and regressive phases reveal a reduced organic carbon content, the dominance of shallow-digging infauna and an increased diversity.

\section{Acknowledgements}

The participation of J. Nagy in this research has been supported by the Statoil/Hydro VISTA programme. The contribution of M. Reolid and F.J. Rodríguez-Tovar has been supported by the projects CGL2005-06636-C0201 and CGL2005-0316/BTE, the EMMI group (RNM-178, Junta de Andalucía) and the Acción Integrada 30.AI.PO.1300 (University of Granada-University of Oslo). A grant of the Universidad de Jaén financed M. Reolid's short stay at the University of Oslo.

\section{References}

Århus N. 1998. Palynostratigraphy of some BathonianHauterivian sections in the Arctic, with emphasis on the Janusfjellet Formation type section, Spitsbergen. Institutt for Kontinentalsokkelundersøkelser og Petroleumsteknologi AS (IKU Sintef-gruppen) Report 23.1252.11/01/88. Trondheim: SINTEF Petroleum Research.

Bąk K. 2004. Deep-water agglutinated foraminiferal changes across the Cretaceous/Tertiary and Palaeocene/Eocene transitions in the deep flysch environment; eastern Outer Carpathians (Bieszczady Mts, Poland). In M. Bubik $\delta$ M.A. Kaminski (eds.): Proceedings of the Sixth International Workshop on Agglutinated Foraminifera. Grzybowski Foundation Special Publication 8. Pp. 1-56. Krakow: Grzybowski Foundation.

Chamney T.P. 1976. Foraminiferal morphogroup symbol for paleoenvironmental interpretation of drill cutting samples: Arctic America, Albian continental margin. Maritime Sediments, Special Publication 18, 585-624.

Dypvik H., Nagy J., Eikeland T.A., Backer-Owe K. \& Johansen H. 1991. Depositional conditions of the Bathonian to Hauterivian Janusfjellet Subgroup, Spitsbergen. Sedimentary Geology 72, 55-78.

Jones R.W. \& Charnock M.A. 1985. "Morphogroups" of agglutinating foraminifera. Their life position, feeding habits and potential applicability in (paleo)ecological studies. Revue de Paléobiologie 4, 311-320.

Nagy J. 1992. Environmental significance of foraminiferal morphogroups in Jurassic North Sea deltas. Palaeogeography, Palaeoecology, Palaeoclimatology 95, 111-134.

Nagy J. \& Basov V.A. 1998. Revised foraminiferal taxa and biostratigraphy of Bathonian to Ryazanian deposits in Spitsbergen. Micropaleontology 44, 217-255.

Nagy J., Grandstein F.M., Kaminski M.A. \& Holbourn A.E. 1995. Foraminiferal morphogroups, paleoenvironments and new taxa from Jurassic to Cretaceous strata of Thakkhola, Nepal. In M.A. Kaminski et al. (eds.): 
Proceedings of the Fourth International Workshop on Agglutinated Foraminifera. Grzybowski Foundation Special Publication 3. Pp. 181-209. Krakow: Grzybowski Foundation.

Nagy J., Løfaldi M. \& Bäckström S.A. 1988. Aspects of foraminiferal distribution and depositional conditions in Middle Jurassic to Early Cretaceous shales in eastern Spitsbergen. Abhandlungen der Geologischen Bundesanstalt 30, 297-300.

Reolid M., Rodríguez-Tovar F.J., Nagy J. \& Olóriz F. 2008. Benthic foraminiferal morphogroups of mid to outer shelf environments of the Late Jurassic (Prebetic Zone, southern Spain): characterization of biofacies and environmental significance. Palaeogeography, Palaeoecology, Palaeoclimatology 261, 280-299.

Severin K.P. 1983. Test morphology of benthic foraminifera as a discriminator of biofacies. Marine Micropaleontology 8 , $65-76$.

Szydlo A. 2004. The distribution of agglutinated foraminifera in the Cieszyn Basin, Polish Outer Carpathians. In M. Bubik \& M.A. Kaminski (eds.): Proceedings of the Sixth International Workshop on Agglutinated Foraminifera. Grzybowski Foundation Special Publication 8. Pp. 461-470. Krakow: Grzybowski Foundation.

Tyszka J. 1994. Response of Middle Jurassic benthic foraminiferal morphogroups to dysoxic/anoxic conditions in the Pieniny Klippen Basin, Polish Carpathians. Palaeogeography, Palaeoecology, Palaeoclimatology 110, 55-81.

\section{Appendix: foraminiferal species by morphogroups and subgroups}

\section{Morphogroup A}

Rhizammina sp.

\section{Morphogroup B}

Thuramminoides lapilliformis Nagy \& Basov, 1998; Thuramminoides sp.

\section{Morphogroup C}

Subgroup $\mathrm{Cl}$

Reophax sterkii Haeusler, 1890

Subgroup C2

Ammobaculites areniferus Nagy \& Basov, 1998; Ammobaculites suprajurassicum (Schwager, 1865); Ammobaculites sp.; Bulbobaculites aff. elongatulus (Dain, 1972).

Subgroup C3

Dorothia sp.; Eomarsonella paraconica Levina, 1972; Verneuilina sp.; Verneuilinoides aff. graciosus Kosyreva, 1972; Verneuilinoides sp.

\section{Morphogroup D}

\section{Subgroup D 1}

Ammoglobigerina canningensis (Tappan, 1955); Trochammina kosyrevae Levina, 1972; Trochammina aff. minutissima Dain, 1972; Trochammina misinovi Levina, 1972; Trochammina praerosacea Nagy \& Basov, 1998; Trochammina rostovzevi Levina, 1972; Trochammina sp.; Trochammina spp.

Subgroup D2

Cribrostomoides subretusus Nagy \& Basov, 1998; Cribrostomoides sp.; Haplophragmoides canuiformis Dain, 1972; Haplophragmoides sp.; Recurvoides disputabilis Dain, 1972; Recurvoides aff. disputabilis Dain, 1972; Recurvoides scherkalyensis Levina, 1962; Recurvoides aff. scherkalyensis Levina, 1962; Recurvoides sp.

\section{Morphogroup E}

Ammodiscus aff. pseudoinfimus Gerke \& Sossipatrova, 1961; Ammodiscus sp.; Arenoturrispirillina jeletzkyi Chamney, 1971; Glomospira oxfordiana Sharovskaja, 1966; Glomospira semiaffixa Sharovkaja, 1966. 